\title{
A JÖVŐ ÚJRAFELFEDEZÉSE KONFERENCIA ÉS FOGADÁS
}

DOI 10.35402/kek.2021.2.6

A konferencia keretében köszöntjük a 85. születésnapját ünneplő László Ervin professzort, az MTA külső tagját, a Budapest Klub elnökét.

\section{Felkért előadók:}

Bándi Gyula - egyetemi tanár, Környezetjogi és Versenyjogi Tanszék, Pázmány Péter Katolikus Egyetem, a Budapest Klub felügyelőbizottságának elnöke

Baráth Etele - volt Európa-ügyi miniszter, a Budapest Klub kuratóriumának tagja

Demcsák Mária - alapító-föszerkesztő, Piac és Profit

Hajnal Klára - adjunktus, Társadalomföldrajzi és Urbanisztikai Tanszék, PTE TTK

Halm Tamás - a Budapest Klub Kuratóriumának tagja, a BGF felnőttképzés igazgatója

Kerekes Sándor - egyetemi tanár, Budapesti Corvinus Egyetem, Kaposvári Egyetem, a Budapest

Klub kuratóriumának tagja

Koncz Gábor - egyetemi magántanár, főiskolai tanár, a TIT Stúdió Egyesület igazgatója

Palkó Zsolt - ügyvezető igazgató, Ecolife Magazin

Rechnitzer János - egyetemi tanár, az MTA Regionális Tudományok Bizottsága elnöke

Sági Mária - a Budapest Klub tudományos igazgatója

Szlávik János - egyetemi tanár, Eszterházy Károly Egyetem, a Budapest Klub kuratóriumának tagja

Tóthné Szita Klára - egyetemi tanár, Regionális és Környezeti Gazdaságtan Mesterszak, Miskolci Egyetem

Vitányi Iván - nyugalmazott egyetemi tanár, volt parlamenti képviselö, a Budapest Klub alapító tagja

\section{PROGRAM}

14:45 Regisztráció

15:00 Rechnitzer János

"Gondolatok egy születésnap alkalmából"

Halm Tamás

„Laudáció”

Vitányi Iván

„Mítosz, lógosz, hólosz”

Bándi Gyula

„A jog szerepe a változásokban” 
Kerekes Sándor

„A Római Klubtól a Budapest Klubig”

Szlávik János

„Gondolatok a tudat forradalmáról” (László Ervin művei alapján)

Hajnal Klára

„Paradigmaváltás a felsőoktatásban”

16.45 Kávészünet

17.10 Tóthné Szita Klára

„Életciklus-szemlélet a jövőkutatásban”

Demcsák Mária

„Üzleti etikus gondolkodásmód elterjedése”

Palkó Zsolt

„A jövő újrafelfedezése a gyakorlatban”

Sági Mária

„Az információ szerepe az új paradigmában”

László Ervin

„Munkásságom lényege - egy rövid áttekintés”

Levezető elnök: Koncz Gábor

\section{FOGADÁS:}

\subsection{Filmvetités}

László Ervin zongorázik a Gaia Symphony című japán filmben (részlet)

Pohárköszöntö

Baráth Etele köszönti László Ervint

Köszöntés a Budapest Klub és a nemzetközi hálózat részéröl

Sági Mária, Anne-Marie Voorhoeve, és Ruzsa Ágota köszönti László Ervint

A Budapest Klub Global Executive Council tagjainak avatása

Fogadás

\section{Médiapartnerek:}

\section{PIAC $\odot$ PROF/T O}

Szerkesztőségünk a konferencia köszöntőinek nyilvánosságra hozatalával igyekszik hozzájárulni a planetáris tudat szélesebb körü megismertetéséhez és László Ervin professzor törekvései méltatásához. 